\title{
Sanitary quality of the public groundwater supply for the municipality of Belém in Northern Brazil
}

\author{
Qualidade sanitária da água do manancial de superfície utilizado pelo \\ serviço de abastecimento público do município de Belém, Pará, Brasil
}

\author{
Rodrigo Santos de Oliveira ${ }^{1}$, Daniela Mayumi Kiyatake², \\ Maria Lúcia Harada ${ }^{3}$, Karla Tereza Silva Ribeiro ${ }^{4}$
}

\begin{abstract}
The present study verified the quality of the water of Água Preta Lake, which is part of the public supply for the Northern Brazilian municipality of Belém (Pará State). Six samples were collected from each of six sampling points. The concentration (NMP) of coliforms was determined by Multiple-tube fermentation Technique. The isolates of Escherichia coli obtained from the samples were tested for susceptibility to the antibiotics (cefoxitin, ampicillin, imipenem, gentamicin, and amikacin). Furthermore, was analyzed the presence of diagnostic genes for the diarrheagenic strains of $E$. coli. None of the genes was identified, however, the recorded concentrations of thermo-tolerant coliforms were within the recommended limits for standing water sources used for public supplies. Nevertheless, the highest concentrations of total and thermo-tolerant coliforms were recorded at two points, one adjacent to the most densely-populated area of the lake margin, and the other near the catchment area for water from the Guamá River. The susceptibility testing indicated the presence of six resistance phenotype profiles, including multi-resistant strains. The results of the study reinforce the need for the systematic monitoring of this water source, in order to provide guidelines for the development of effective management policies for public water supplies, as well as the prevention of water-borne diseases. Keywords: enterobacteriaceae; escherichia coli; water supply.
\end{abstract}

\begin{abstract}
Resumo
Neste estudo, a qualidade da água foi verificada no manancial de abastecimento Água Preta, do município de Belém (PA). Houve seis amostragens em seis pontos de coleta e a concentração de coliformes foi verificada através da Técnica de Fermentação em Tubos Múltiplos para a determinação do NMP. Os isolados de Escherichia coli obtidos foram submetidos ao teste de sensibilidade aos seguintes antimicrobianos: cefoxitina, ampicilina, imipenem, gentamicina e amicacina. Além disso, foi investigado genes codificadores de fatores de virulência relacionados às variedades diarreiogênicas de $E$. coli. Não houve ocorrência de genes relacionados à patogenicidade, e as concentrações de coliformes termotolerantes apresentaram-se dentro dos padrões para mananciais de superfície usados para fins de abastecimento público. Contudo, as maiores concentrações de coliformes totais e termotolerantes foram observadas no ponto de coleta próximo à captação no rio Guamá e na área de maior adensamento populacional no entorno do lago. O teste de suscetibilidade dos isolados $E$. coli indicou uma alta porcentagem de resistência a ampicilina, a presença de seis perfis fenotípicos e a ocorrência de multiresistência. Assim, os resultados reforçam a necessidade do monitoramento sistemático deste manancial, visando a implementação de políticas de preservação e proteção dos mananciais utilizados para fins de abastecimento público, assim como a prevenção de doenças veiculadas pela água.

Palavras-chave: enterobacteriaceae; escherichia coli; abastecimento de água
\end{abstract}

Study carried out at Instituto de Ciências Biológicas, Universidade Federal do Pará (UFPA) - Belém (PA), Brasil.

${ }^{1}$ Mestre em Biotecnologia. Laboratório de Microbiologia Ambiental, Instituto de Ciências Biológicas, UFPA - Belém (PA), Brasil.

${ }^{2}$ Mestre em Ecologia Aquática e pesca. Laboratório de Microbiologia Ambiental, Instituto de Ciências Biológicas, UFPA - Belém (PA), Brasil.

${ }^{3}$ Doutora em Ciências Biológicas. Laboratório de Biologia Molecular "Francisco Mauro Salzano", Instituto de Ciências Biológicas, UFPA - Belém (PA), Brasil.

${ }^{4}$ Doutora em Desenvolvimento Sustentável do Tópico Úmido - Laboratório de Microbiologia Ambiental, Instituto de Ciências Biológicas, UFPA - Belém (PA), Brasil. Correspondence to: Rodrigo Santos de Oliveira - Laboratório de Microbiologia Ambiental, Instituto de Ciências Biológicas, UFPA - Rua Augusto Corrêa -

CEP: 66075-110 - Belém (PA), Brasil - E-mail: rodrigodeoliveira01@gmail.com

Financial support: CNPq (Edital MCT/CNPq 02/2006 - Universal)

Conflict of interests: nothing to declare. 


\section{INTRODUCTION}

Worldwide, many cities face a critical shortage of adequate supplies of freshwater. This problem is not only a question of the spatial distribution of this resource, but also involves the quality of sources, given that, in most countries, ongoing population growth and expansion of economic activities are provoking an increasing scarcity of reliable supplies of water of good quality, placing limits on both economic development and public health ${ }^{21-25}$.

In Brazil, aquatic systems suffer a number of anthropogenic impacts from activities such as deforestation, the discharge of industrial residues, overuse of agricultural pesticides, and in particular, deficient or nonexistent public sanitation ${ }^{21}$. The United Nations Children's Fund (UNICEF) and the World Health Organization (WHO) have estimated that some 2.6 billion people worldwide lack basic sanitation, and that almost one billion have no access to an adequate supply of drinking water ${ }^{23}$. These conditions provide a favorable environment for the establishment and propagation of infectious diseases. It has been estimated that $80 \%$ of all the infectious diseases in developing countries are linked to the consumption of contaminated drinking water, in particular diarrheas, which affect the infant population primarily ${ }^{8-6}$.

Unlike many other parts of the world, the Brazilian Amazon region has a surplus of freshwater, although supplies of water adequate for human consumption are limited, given the lack of investment in public sanitation and the rapid growth of most of the region's cities ${ }^{27}$. For example, most of the hydrographic basin of the city of Belém, in the Brazilian State of Pará, is affected by the unregulated discharge of chemical waste, solid residues, and other domestic and industrial effluents, which are deposited untreated into the rivers and streams region, and ultimately make their way into the public water supply ${ }^{27}$.

Regarding to the importance of the protection of public water supplies and the need for the prevention of water-borne diseases, the present study analyzed the microbiological quality of the water of Água Preta Lake in the Brazilian city of Belém. This lake is one of the principal sources for the city's public water supply.

\section{MATERIAL AND METHODS}

\section{Study area}

Samples were taken from Água Preta Lake, located in Belém Environmental Reserve (created in the State Decree No 1552 of 03/05/93), belonging to Utinga region ${ }^{27}$. Along with Bolonha Lake, is responsible for supplying approximately two-thirds of the population of the metropolitan area of
Belém with running water ${ }^{12}$, presents an area of $3.116 .860 \mathrm{~m}^{2}$ and $9.950 .000 \mathrm{~m}^{3}$ volume, being influenced by the waters of the Guamá River (Figure 1) ${ }^{19}$. This influence is related to the pickup point Guama River water to the lake, in order to supplement the volume of water to supply the metropolitan area of Belém. Although situated in an area of environmental protection, provides point of human occupation due to disordered development of the city.

As described in Resolution no 357/2005 of CONAMA to fresh water environment, this aquatic ecosystem fits for class 2 , because is intended for human consumption, after a conventional treatment ${ }^{2}$. Furthermore, according to this resolution, require monitoring (without prior aseptic water testing), due to be a supplying aquatic environment, needs be agree quality parameters of CONAMA, to be used to this purpose ${ }^{2}$.

\section{Sample collection}

Six water samples were collected at each of six points in Água Preta Lake (Figure 1) between June 2007 and June 2008. The sampling points were selected according to the influence sphere around the lake. The U1, U2 and U5 points are close to conserved regions of forest. The U3 is the closest to pickup point Guama River water to the lake. The U4 is the closest to the visitor center of the environmental reserve. The point U6 is the closest to pickup point Água Preta Lake water to the Bolonha Lake.

The samples were collected, transported and stored, according to the procedures outlined in the Standard Methods for the Examination of Water and Wastewater, $20^{\text {th }}$ edition ${ }^{3}$.

Following the recommendations of the Standard Methods for the Examination of Water and Wastewater ${ }^{3}$, the samples were with the aid of polypropylene vials, properly sterilized with the ability to $100 \mathrm{~mL}$. Each vial was placed against the water flow, at a depth of $30 \mathrm{~cm}$. After collecting, the vials were properly identified and stored in an isothermal box to the laboratory examination.

\section{Quantification of total and Thermotolerant coliforms}

The Qualification of Total (TC) and Thermotolerant Coliforms (ThC) concentrations were estimated using the multiple tube fermentation technique. During the preliminary stage, the water samples were diluted from $10^{-1}$ to $10^{-4}$ and then inoculated with $1 \mathrm{~mL}$ of each dilution in tubes containing lactose broth. Following incubation at $35 \pm 0.5^{\circ} \mathrm{C}$ for $24-48$ hours the turbidity of the liquid and the production of gas was verified in inverted Durham tubes. Aliquots of the positive tubes were transferred to test tubes 2\% Brilliant Green Lactose Bile Broth (BGLBB) and Escherichia coli Broth (ECB). The tubes containing BGLBB were then incubated in a water bath at 


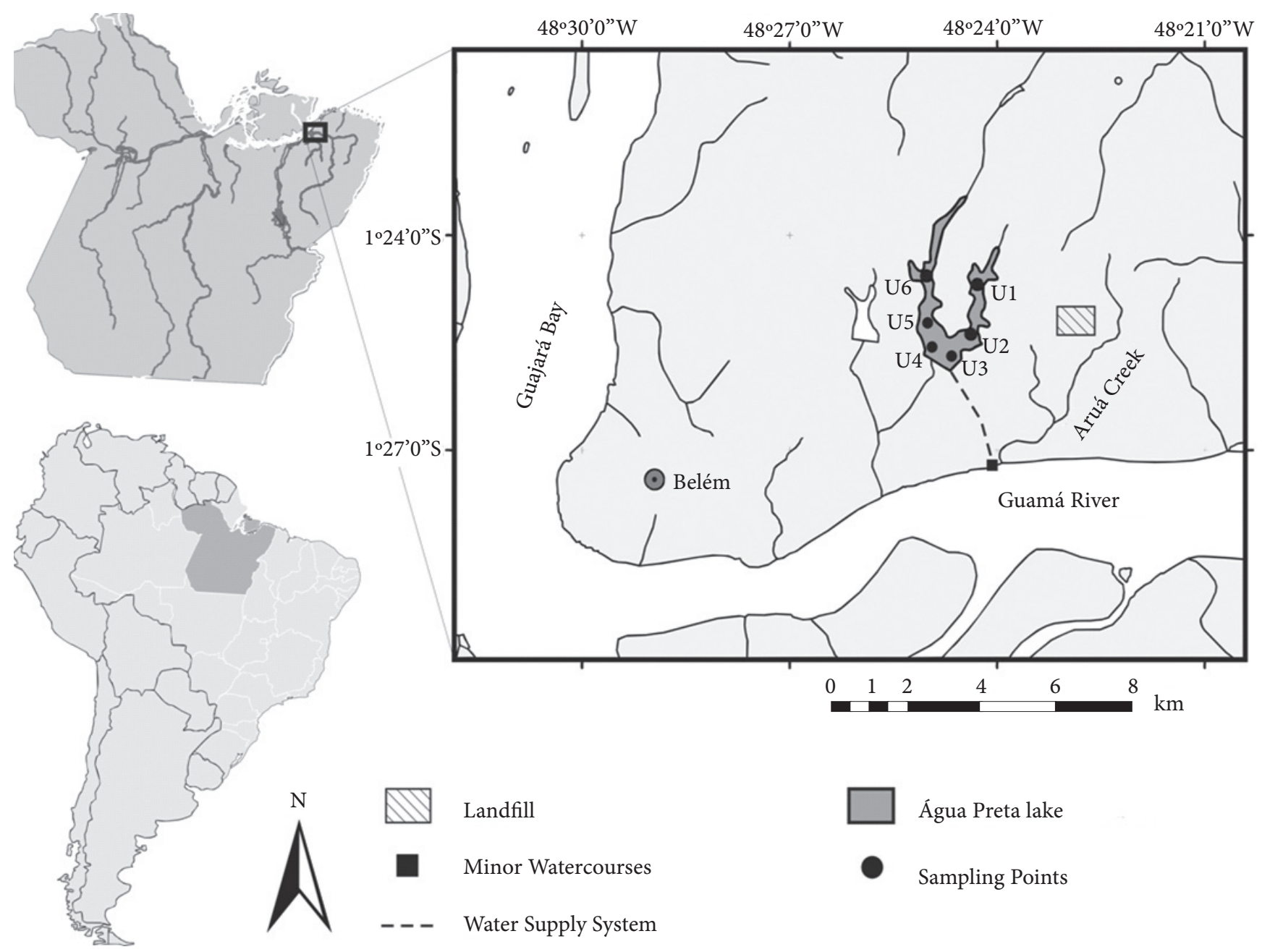

Figure 1. Location of Água Preta Lake regarding to the Northern Brazilian city of Belém (Pará State) and its principal tributaries. The sampling points are labeled as in the text

$35 \pm 0.5^{\circ} \mathrm{C}$ for $24-48$ hours, and those with ECB at $44.5 \pm 0.2^{\circ} \mathrm{C}$ for 24 hours. Then, the tubes were analyzed to determine the Most Probable Number (MPN) of coliforms using the Hoskins table, which considers a $95 \%$ confidence interval, according to the procedure described in the Standard Methods for the Examination of Water and Wastewater, $20^{\text {th }}$ edition ${ }^{3}$.

\section{Identification of Escherichia coli}

For the isolation and identification of E. coli, aliquots were extracted from the positive BGLBB cultures and transferred to the surface of a MacConkey agar medium followed by incubation at $35.0 \pm 0.5^{\circ} \mathrm{C}$ for 24 hours. The colonies typical of lactosefermenting bacteria were selected for biochemical identification, using the procedure described by Koneman et al. ${ }^{14}$.

\section{Profile of the susceptibility of Escherichia coli to antibiotics}

The resistance or sensitivity of the E. coli isolates confirmed by the biochemical analyses to cefoxitin $(30 \mathrm{mcg})$, ampicillin $(10 \mathrm{mcg})$, imipenem $(10 \mathrm{mcg})$, gentamicin $(10 \mathrm{mcg})$, and amikacin $(30 \mathrm{mcg})$ was examined using the disk-diffusion test in Mueller Hinton agar plates. This test was conducted according to the recommendations of the Clinical and Laboratory Standards Institute, CLSI ${ }^{1}$.

\section{Detection of the genes related to pathogenicity in the Escherichia coli isolates}

The identification of bacterial lineages with pathogenic potential was based on the Polymerase Chain Reaction (PCR) technique, which was used to amplify specific genes (Table 1), following established procedures.

\section{Extraction of the DNA}

Each lineage was cultured in nutrient broth for 24 hours at $37^{\circ} \mathrm{C}$, and then centrifuged at $7000 \mathrm{rpm}$ for 5 minutes. The pellet was dissolved in T.E. buffer and treated with $\mathrm{K}$ protease $(10 \mathrm{mg} / \mathrm{mL})$ for 30 minutes at $55^{\circ} \mathrm{C}$. The DNA was then extracted using phenol-chloroform (1:1) and chloroform isoamyl alcohol (24:1). 


\section{Pathogenic markers test}

Five marker genes were selected and amplified according to the procedure outlined in the respective reference (Table 1). The amplified fragments were visualized in $1 \%$ agarose gel. The standardized pathogenic EPEC, ETEC, and EHEC strains, which were provided by the Evandro Chagas Institute in Belém, were used as positive controls for the PCR.

\section{STATISTICAL ANALYSES}

The MPN data for total and thermo-tolerant coliforms were examined for normality using the Shapiro-Wilk test. Due to normality was not confirmed, the Kruskal-Wallis nonparametric analysis of variance was used to investigate the significance of the observed variation in coliform concentrations among the different sampling points. Spearman's correlation coefficient was used to verify the possible relationship between coliform concentrations (total and thermo-tolerant) and monthly precipitation. Rainfall records were obtained from the Pará State ministry for Science, Technology, and the Environment (http://www.para30graus.pa.gov.br/precipitacoes_mensal.htm). A significance level of $\alpha=0.05$ was adopted for all statistical analyses.

\section{RESULTS}

Quantification of Total (TC) and Thermotolerant coliforms (ThC) - The TC concentration varied from $4.5 \times 10^{1}$ to $1.7 \times$ $10^{3} \mathrm{NMP} / 100 \mathrm{~mL}$, while that of ThC ranged from $2.0 \times 10^{1}$ to $4.9 \times 10^{2} \mathrm{NMP} / 100 \mathrm{~mL}$. No systematic correlation was found between the concentrations of either parameter and monthly precipitation during the study period (TC: Spearman's $\mathrm{r}_{\mathrm{s}}=-0.095, \mathrm{p}=0.8$; ThC: $\left.\mathrm{r}_{\mathrm{s}}=-0.143, \mathrm{p}=0.7358\right)$.

Significant variation in the MPN was found among the different sampling points only for thermo-tolerant coliforms (Kruskal-Wallis' $\mathrm{H}=16.5217, \mathrm{n}=5,48, \mathrm{p}=0.0055)$ ), indicating the possible influence of different portions of the lake on the concentrations of these bacteria. Points U3 and U6 returned the highest concentrations, and thus the highest median values (Figure 2).

Isolation of coliforms - Four different coliform species were identified in the samples. Escherichia coli was the most common, appearing in $31 \%$ of the samples, followed by Klebsiella sp. (22\%), Enterobacter sp. (10\%), and Citrobacter sp. (2\%).

Profile of the susceptibility of E. coli to antibiotics - All of the $30 \mathrm{E}$. coli isolates were susceptible to imipenem $(10 \mathrm{mcg})$, gentamicin $(10 \mathrm{mcg})$, and amikacin $(30 \mathrm{mcg})$. In the case of ampicillin, however (Table 2), while some strains were sensitive to this antibiotic, others were partially or completely resistant. Similarly, some of the strains presented intermediate resistance to cefoxitin, whereas others were susceptible. The results of this analysis permitted the identification of six distinct phenotypic profiles (A-F), some of which were multiresistant (Table 3).

Pathogenic genes - None of the 30 E. coli isolates contained any of the genes targeted by the analysis (Table 1).

\section{DISCUSSION}

The lack of adequate public sanitation measures is an ongoing problem, which poses a serious risk to public health, as well as causes an impact to the aquatic ecosystems ${ }^{24}$. In the cities of the Amazon region, in particular, this problem is exacerbated by the general lack of urban planning ${ }^{27}$.

In the present case, while the land adjacent to the Água Preta Lake is considered to be a protected area due to the presence of sources of public water supplies, it is densely populated by squatters. Worse still, during the visits to the lake for the collection of the water samples, it was possible to confirm that the residences located within this area lacked any form of public sanitation, and that domestic waste was being discharged untreated into the margins of the lake. The local residents also dump solid waste in the area, exploit the natural resources of the remaining forest, and fish in the lake.

Table 1. Pathogenic genes investigated in the present study, and their respective primers

\begin{tabular}{|c|c|c|c|c|}
\hline Primer pair & Target gene & Primer Sequence $\left(5^{\prime}\right.$ to $\left.3^{\prime}\right)$ & Product size (bp) & Reference \\
\hline BfpB-F & \multirow{2}{*}{ BfpB } & GATGGGGCTGATACTGGGCAGC & \multirow[b]{2}{*}{826} & \multirow{2}{*}{ Müller et al. ${ }^{22}$} \\
\hline BfpB-R & & AGTGACTGTTCGGGAAGCAC & & \\
\hline Stxla-F & \multirow{2}{*}{ Stxla } & GGCGTTCTTATGTAATGACTGC & \multirow{2}{*}{250} & \multirow{2}{*}{ Müller et al. ${ }^{22}$} \\
\hline Stx1a-R & & ATCCCACGGACTCTTCCATC & & \\
\hline eae-F & \multirow{2}{*}{ eae } & ATTACTGAGATAAGGCTGAT & \multirow{2}{*}{682} & \multirow{2}{*}{ Blanco et al. ${ }^{4}$} \\
\hline eae-F & & ATTTATTTGCAGCCCCCAT & & \\
\hline STIa 1 & \multirow{2}{*}{ STIa } & TCTGTATTATCTTTCCСCTC & \multirow{2}{*}{186} & \multirow{2}{*}{ Schultsz et al..$^{28}$} \\
\hline STIa 2 & & ATAACATCCAGCACACAGGC & & \\
\hline LTa 1 & \multirow{2}{*}{$\mathrm{LTa}$} & GGCGACAGATTATACCGTGC & \multirow{2}{*}{696} & \multirow{2}{*}{ Schultsz et al. ${ }^{28}$} \\
\hline LTa 2 & & CCGAATTCTGTTATATATGTC & & \\
\hline
\end{tabular}




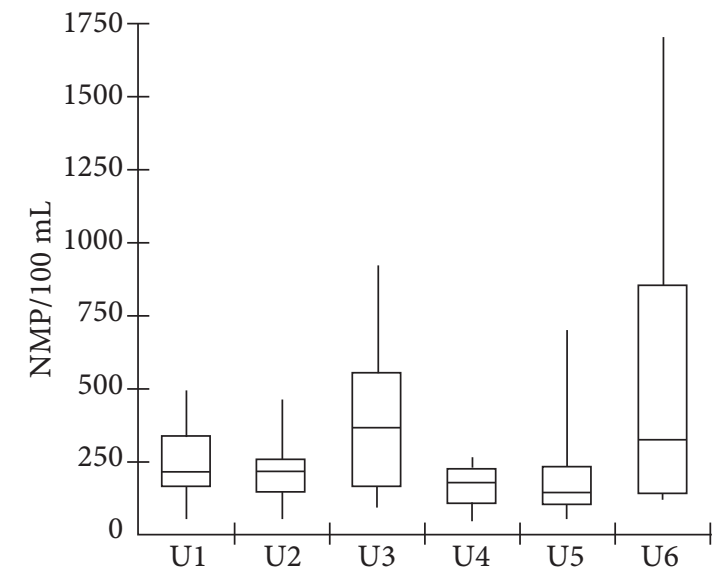

II

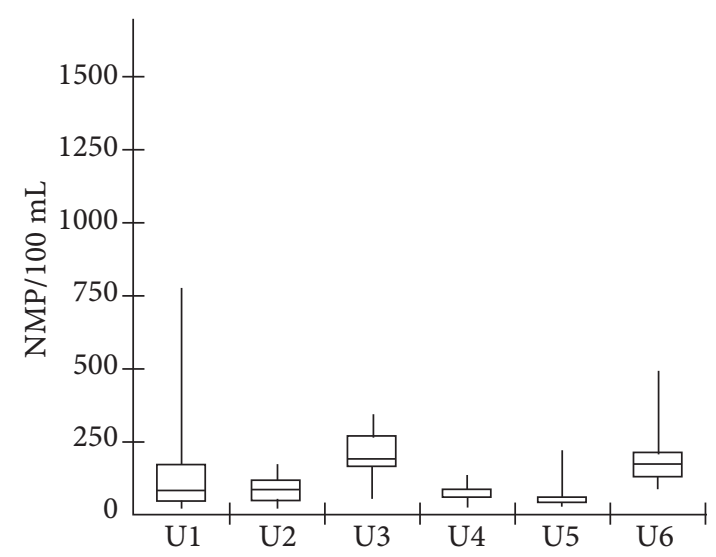

Figure 2. Box plot (median and quartiles) of the concentrations of total coliforms (I), and thermo-tolerant coliforms (II) recorded at the different sampling points in Água Preta Lake in the Brazilian city of Belém

Table 2. Susceptibility of the Escherichia coli strains isolated from the water of Água Preta Lake (Belém) to the antibiotics Ampicillin (10 mg) and Cefoxitin $(10 \mathrm{mg})$

\begin{tabular}{|c|c|c|c|c|c|c|}
\hline \multirow{2}{*}{ Sample point } & \multirow{2}{*}{$\begin{array}{l}\text { Number } \\
\text { of isolates }\end{array}$} & \multicolumn{3}{|c|}{ Susceptibility to Ampillicin (\%) } & \multicolumn{2}{|c|}{ Susceptibility to Cefoxitin (\%) } \\
\hline & & Resistant & Intermediate & Sensitive & Intermediate & Sensitive \\
\hline U1 & 13 & 53.85 & 15.38 & 30.77 & 61.54 & 38.46 \\
\hline $\mathrm{U} 2$ & 4 & 25.00 & 50.00 & 25.00 & 0.00 & 100.00 \\
\hline U3 & 7 & 14.29 & 28.57 & 57.14 & 42.68 & 57.14 \\
\hline $\mathrm{U} 4$ & 4 & 0.00 & 50.00 & 50.00 & 25.00 & 75.00 \\
\hline U5 & 1 & 100.00 & 0.00 & 0.00 & 0.00 & 100.00 \\
\hline U6 & 1 & 0.00 & 100.00 & 0.00 & 0.00 & 100.00 \\
\hline
\end{tabular}

Table 3. Phenotypic profiles of the Escherichia coli strains isolated from the water of Água Preta Lake (Belém) obtained from the disk diffusion tests

\begin{tabular}{lcccccc} 
& Number & \multicolumn{3}{c}{ Susceptibility to } \\
\cline { 3 - 6 } Phenotype & of isolates & Cefoxitin & Ampicillin & Imipenem & Gentamicin & Amikacin \\
A & 8 & Sensitive & Sensitive & Sensitive & Sensitive & Sensitive \\
B & 6 & Intermediate & Sensitive & Sensitive & Sensitive & Sensitive \\
C & 3 & Intermediate & Intermediate & Sensitive & Sensitive & Sensitive \\
D & 3 & Intermediate & Resistant & Sensitive & Sensitive & Sensitive \\
E & 4 & Sensitive & Intermediate & Sensitive & Sensitive & Sensitive \\
F & 6 & Sensitive & Resistant & Sensitive & Sensitive & Sensitive \\
\hline
\end{tabular}

Despite this apparent degradation of the environment, the concentrations of thermo-tolerant coliforms recorded in the present study were within the limits established by the Brazilian National Environment Council (CONAMA: resolution number 357/2005) for freshwater quality (class 2). This classification recommends a concentration of no more than 1.000 coliforms per $100 \mathrm{~mL}$ of water ${ }^{2}$.

Despite the fact that the concentration of thermo-tolerant coliforms recorded in this study was within the limits defined by Brazilian legislation, there is a clear need for the a systematic program of planning and for the protection of these bodies of water development, especially those located within the Area of Environmental Protection (AEP); given that a number of studies, such as that of Viau et al. ${ }^{30}$, have confirmed the negative effects of anthropogenic impacts on these aquatic systems.

Menezes et al. ${ }^{19}$, for example, found that human activities in the area surrounding Água Preta Lake affect the concentration of dissolved oxygen in its water, which is one of the chemical parameters covered in the CONAMA legislation ${ }^{2}$, i.e., resolution 357/2005.

In the present study, significant variation was found in the concentrations of thermo-tolerant coliforms in different parts of the lake, which suggests the influence of specific local 
factors on the quality of the water, possibly related to the presence of urban development in the surrounding area. Points $\mathrm{U} 3$ and U6 presented the highest concentrations in terms of the MPN/100 mL (Figure 2). Point U6 is the closest to the residential area occupied on the margin of the lake (Figure 1), which reinforces the conclusion that anthropogenic impacts are influencing the sanitary quality of the lake's water, in particular related to the lack of a public sanitation system in the urbanized areas on its margins.

Viau et al. ${ }^{30}$ indicated that the lack of public sanitation is one of the principal factors determining the quality of sources of drinking water, and reinforced the need of the adequate monitoring of these aquatic environments.

By contrast, point $\mathrm{U} 3$ is close to the catchment area for the water from the Guamá River (Figure 1). This river is affected by a number of other potentially polluted watercourses, in particular the Aurá stream, which drains the areas surrounding the landfill that serves the whole of the metropolitan zone of Belém ${ }^{12}$. Landfills are known to represent a serious potential risk for the environment, due to the possibility of the chemical or microbiological contamination of aquatic environments from the run-off of slurry ${ }^{19}$.

Mudiam et al. ${ }^{21}$ classifies the presence of total and thermotolerant coliforms as a primary indicator of fecal contamination. While these microorganisms may not necessarily be pathogenic in themselves, their presence indicates the possible occurrence of other, potentially more infectious organisms.

Precipitation rates may affect the concentration of microorganisms in standing water, through the leaching of pathogens, nutrients, sediments, and heavy metals from the surrounding area into the water ${ }^{16}$. In the present study, however, no systematic relationship was found between coliform concentrations and precipitation levels. The inconclusiveness of this analysis may has been a sampling effect, given that Kolm and Andretta ${ }^{13}$ confirmed a significant relationship with both types of coliform concentration, based on a much larger sample.
The relative abundance of $E$. coli in comparison with the other coliforms identified in this study is a further indication of fecal contamination, given that this bacterium is found exclusively in the digestive tract of humans and other warmblooded animals ${ }^{10}$. This microorganism is used as a primary indicator of fecal contamination by many European countries, as well as the WHO, in its publication Guidelines for Drinking Water Quality9.

The probability of fecal contamination is also confirmed by the relatively high percentage of strains resistant to ampicillin. Many microorganisms are becoming increasingly resistant to widely-used antibiotics, such as ampicillin ${ }^{11}$, and the identification of strains resistant to this antibiotic is further evidence of contamination of human origin. This conclusion is also reinforced by the presence of multi-resistant strains in the present samples (Table 3), which is also evidence of contamination by feces of human origin ${ }^{5}$. The presence of these resistant strains constitutes in a clear risk for public health, especially considering that these lineages may transfer this resistance to other bacteria, including pathogenic species, which may infect the individual that use the contaminated water ${ }^{24}$.

The molecular analysis confirmed that none of the target genes was present in any of the samples. Few data are available on the pathogenic lineages of $E$. coli found in aquatic environments, with the exception of the enterohemorrhagic strain, which produces the toxin Shiga and is related to the Stx 1 gene $^{18}$. However, few studies have identified the Stx 1 gene in aquatic environments ${ }^{7}$, which suggests that it may be relatively difficult to investigate pathogenic genes in this type of environment.

Overall, then, the results of the present study indicate an urgent need of a systematic monitoring of the water of Água Preta Lake in the Utinga Environmental Park, in order to provide guidelines for the development of effective environmental monitoring and public policies that will ensure the preservation and protection of the area surrounding this body of water. These measures will be essential to guarantee a reliable and healthy public water supply for the city of Belém in the future.

\section{REFERENCES}

1. Brasil. Agência Nacional de Vigilância Sanitária. Padronização dos testes de sensibilidade a antimicrobianos por disco-difusão, v. 23, n. 1, 2003. Available from: http://www.anvisa.gov.br/servicosaude/manuais/clsi/ clsi_OPASM2-A8.pdf

2. Brasil. Conselho Nacional do Meio Ambiente- Brasil. 2005. Resolução No 357 de 17 de março de 2005. [cited 2013 Nov 27]. Available from: http://www.mma.gov.br/port/conama/res/res05/res35705.pdf

3. American Public Health Association. Standard Methods for the Examination of Water and Wastewater. Washington: APHA, AWWA, APCF. 2006;21st ed.

4. Blanco M, Blanco JE, Mora A, Rey J, Alonso JM, Hermoso M, et al. Serotypes, virulence genes, and Intim Types of Shiga Toxin (verotoxin)producing Escherichia coli isolates from Healthy Sheep in Spain. J Clin Microbiol. 2003;41:1351-56.

5. Boom PI, Cattanach, M. Antibiotic resistance of native and faecal bacteria isolated from rivers, reservoirs and sewage treatment facilities in Victoria, south-eastern Austrália. Letters Appl Microbiol. 1999;28 (3):164-8.

6. Cairncross S, Hunt C, Boisson S, Bostoen K, Curtis V, Fung ICH, et al. Water, sanitation and hygiene for the prevention of diarrhoea. Int $\mathrm{J}$ Epidemiol. 2010;39:193-205. 
7. Duris JW, Haack SK, Fogarty LR. Gene and antigen markers of Shiga-toxin producing E. coli from Michigan and Indiana river water: Occurrence and relation to recreational water quality criteria. J Environ Qual. 2009;38:1878-86.

8. Fawell J, Nieuwenhuijsen, MJ. Contaminants in drinking water. British Medical Bulletin. 2003;68:199-208.

9. Figueras MJ, Borrego JJ. New Perspectives in Monitoring Drinking Water Microbial Quality Int J Environ Res Public Health. 2010;7:4179-202.

10. Hamelin K, Bruant G, El-Shaarawi A, Stephen H, Edge TA, Fairbrother $\mathrm{J}$, et al. Occurrence of virulence and antimicrobial resistance genes in Escherichia coli isolates from different aquatic ecosystems within the St. Clair River and Detroit River Areas. Appl Environ Microbiol. 2007;73(2):477-84.

11. Harwood VJ, Whitlock J, Withington V. Classification of antibiotic resistance patterns of indicator bacteria by discriminant analysis: Use in predicting the source of fecal contamination in subtropical waters. Appl Environ Microbiol. 2000;66(9):3698-704.

12. Imbiriba Junior $\mathrm{M}$, Costa FR. Recursos Hídricos: $\mathrm{O}$ caso dos mananciais dos lagos Bolonha e Água Preta na Região Metropolitana de Belém. XXXIII Assembleia Nacional da ASSEMAE. 2003. Santo André, SP. [cited 2013 Nov 27]. Available from: www.semasa.sp.gov.br/Documentos/ ASSEMAE/Trab_108.pdf

13. Kolm HE, Andretta L. Bacterioplancton in the different tides of the Perequê tidal creek, Pontal do Sul, Paraná, Brazil. Braz J Microbiol. 2003;34:97-103.

14. Koneman, EW, Winn WC. Diagnóstico microbiológico: texto and atlas colorido. 6. ed. Rio de Janeiro: Guanabara Koogan; 2006. 1760 p.

15. Kurz R, Hardwood, V, Rose J, Lim D. Using bacterial source tracking and other innovative techniques to identify sources of fecal contamination in stormwater. Proceedings of the Seventh Biennial Stormwater Research and Watershed Management Conference. Sarasota: Florida. 2006; p. 60.

16. Leclerc H, Mossel DAA, Edberg SC, Struijk SB. Advances in the bacteriology of the coliform group: Their suitability as markers of microbial water safety. Annu Re Microbiol. 2001;55:201-34.

17. Lothigius A, Sjöling A, Svennerholm AM, Bölin I. Survival and gene expression of enterotoxigenic Escherichia coli during long-term incubation in sea water and freshwater. J Appl. Microbiol. 2009;108 (4):1441-9.

18. Matejczyk M, Płaza GA, Nałe،cz-Jawecki G, Ulfig K, MarkowskaSzczupak A. Estimation of the environmental risk posed by landfills using chemical, microbiological and ecotoxicological testing of leachates. Chemosphere. 2011;82:1017-23.
19. Menezes LBC, Braz VN, Queiroz SAR, Santos EC. Perfil de oxigênio dissolvido nos Lagos Bolonha e Água Preta, Utinga, Belém-PA. VI Simpósio Italo-Brasileiro de Engenharia Sanitária and Ambiental. 2006. Vitória, ES. [cited 2013 Nov 27]. Available from: http://www.bvsde.paho. org/bvsacd/sibesa6/ccxi.pdf

20. Moraes DSL, Jordão BQ. Degradação de recursos hídricos and seus efeitos sobre a saúde humana. Rev Saúde Pública. 2002;36(3):370-4.

21. Mudiam MKR, Pathak SP, Gopal K, Murthy RC. Studies on urban drinking water quality in a tropical zone. Environ. Monit. Assess. 2012 [cited 2012 May 25]. Available from: http://www.springerlink.com/ content/k52q3862766305h8

22. Müller D, Hagedorn, Brast S, Heusipp G, Bielaszewska M, Friedrich AW, et al. Rapid identification and differentiation of clinical isolates of Enteropathogenic Escherichia coli (EPEC), Atypical EPEC, and Shiga Toxin-Producing Escherichia coli by a one-step multiplex PCR method. J Clin Microbiol. 2006;44:2626-9.

23. Olaniran AO, Naicker K, Pillay. Antibiotic resistance profiles of Escherichia coli isolates from river sources in Durban, South Africa. World J Microbiol Biotechnol. 2009;25:1743-49.

24. Olmstead SM. The economics of water quality. Rev Environ Econ Policy. 2010;4(1):44-62.

25. Perz SG. The quality of urban environments in the Brazilian Amazon. Soc Indic Res. 2000;49:181-212.

26. Ram S, Vajpayee P, Singh RL, Shanker R. Surface water of a perennial river exhibits multi-antimicrobial resistant Shiga toxin and Enterotoxin producing Escherichia coli. Ecotox Environ Safe. 2009;72:490-5.

27. Ribeiro KTS. Água e Saúde Humana em Belém. Belém: Cejup; 2004.

28. Schultsz C, Pool GJ, Ketel R, Wever B, Speelman P, Dankert J. Detection of Enterotoxigenic Escherichia coli in stool samples by using nonradioactively labeled oligonucleotide DNA probes and PCR. J Clin Microbiol.1994;32:2393-7.

29. United Nations Children's Fund. Organização Mundial de Saúde. Progressos no acesso a água potável; necessidades de saneamento requerem maiores esforços. 2010. [cited $2013 \mathrm{Nov}$ 27]. Available from: http://www.unicef.pt/18/10_03_15_pr_agua_saneamto_1.pdf

30. Viau EJ, Goodwin KD, Yamaha KM, Layton BA, Sassoubre LM, Burns SL, et al. Bacterial pathogens in Hawaiian coastal streams Associations with fecal indicators, land cover, and water quality. Water Research. 2011. [cited 2013 Nov 27]. Available from: http://www.ncbi.nlm.nih.gov/ pubmed/21492899

Received on: 03/27/2013

Accepted on: 11/19/2013 